\title{
Perancangan Sistem Pendukung Keputusan Pemilihan Supplier Karet Komponen Kaca Mobil Di Bintang Berlian Glass Bandung Dengan Metode AHP (Analytical Hierarchy Process)
}

\author{
Lukman Kurniawan ${ }^{1}$, Hermawaty ${ }^{2}$, Yuyun Tresnawati ${ }^{3}$ \\ 1,2,3 Program Studi Sistem Informasi \\ 1,2,3 STMIK AMIK BANDUNG, J1. Jakarta No. 28 Bandung \\ Email : campione47@gmail.com¹, emma@stmik-amikbandung.ac.id², \\ yuyun@stmik-amikbandung.ac.id ${ }^{3}$
}

\begin{abstract}
ABSTRAK
Bintang Berlian Glass merupakan perusahaan yang bergerak di bidang otomotif. Perusahaan ini menyediakan berbagai komponen mobil yang dibutuhkan bagi calon pembeli baik perusahaan besar seperti Karoseri mobil maupun perorangan. Komponen yang disediakan yaitu kaca mobil dengan berbagai tipe mobil, kaca mobil dengan ukuran sesuai pesanan, macam - macam karet mobil dan menyediakan jasa pemasangan. Pada pengadaan karet komponen, perusahaan ini mengalami kesulitan untuk memilih supplier karet komponen yang memiliki barang dengan kualitas tinggi, harga terjangkau, stok yang melimpah dan jarak yang dekat untuk mendapatkan produk tersebut.

Program pemilihan supplier barang bertujuan untuk membantu dalam pemilihan supplier terbaik. Pemilihan supplier barang ini sangat diharapkan terutama di dalam perusahaan, tidak akan mengalami kekecewaan dalam pemilihan barang tersebut.

Oleh karena itu, mereka membutuhkan sebuah sistem pendukung keputusan yang dapat membantu memilih supplier terbaik secara akurat berdasarkan kriteria yang sudah ditentukan. Sehingga pemilihan supplier barang tidak ada lagi kesalahan. Maka dari itu untuk mempermudah pengambilan keputusan, dalam pemilihan supplier barang ini menggunakan metode Analytical Hierarchy Process karena akan sangat cocok untuk mengambil keputusan yang multi-kriteria, ada berbagai kriteria sebagai parameter pengambilan keputusan yaitu kualitas barang yang konsisten, ketersediaan barang, waktu pengiriman, kemudahan pengembalian, harga barang, pelayanan pelanggan, dan kualitas barang. Dalam penelitian ini dirancang sebuah sistem pendukung keputusan yang bisa mengoptimalkan dalam dalam pemilihan supplier dengan pengembangan sistem menggunakan metode SDLC dan diimplementasikan dengan bahasa pemrograman PHP dan penyimpanan database dengan MySQL. Metode keputusan yang digunakan adalah metode Analytical Hierarchy Process untuk penentuan supplier.

Hasil yang dicapai dari Sistem Pendukung Keputusan ini dapat membantu pihak perusahaan dalam memberikan rekomendasi penentuan supplier, dengan hasil perhitungan Analytical Hierarchy Process menyatakan bahwa supplier yang nilainya lebih tinggi dibandingkan dengan alternatif supplier yang lain adalah CV Garuda Jaya.
\end{abstract}

Kata Kunci : Sistem Pendukung Keputusan, Penentuan Supplier, Supplier, AHP 


\begin{abstract}
Bintang Berlian Glass is a company engaged in the automotive sector. This company provides various car components needed for prospective buyers, both large companies such as car bodies and individuals. The components provided are auto glass with various types of cars, auto glass with sizes to order, various types of car rubber and providing installation services. In the procurement of rubber components, this company has difficulty choosing suppliers of rubber components that have high quality goods, affordable prices, abundant stocks and a short distance to get the product.

Goods supplier selection program aims to assist in selecting the best supplier. The selection of a supplier of this item is expected, especially within the company, will not experience disappointment in the selection of these goods.

Therefore, they need a decision support system that can help choose the best supplier accurately based on predetermined criteria. So that the selection of suppliers of goods is no longer a mistake. Therefore, to facilitate decision making, in selecting suppliers of this item using the Analytical Hierarchy Process method because it will be very suitable for making multi-criteria decisions, there are various criteria as parameters for decision making, namely consistent quality of goods, availability of goods, time of delivery, convenience. returns, price of goods, customer service, and quality of goods. In this study, a decision support system was designed that can optimize supplier selection by developing a system using the SDLC method and implemented with the PHP programming language and database storage with MySQL. The decision method used is the Analytical Hierarchy Process method for determining suppliers.

The results achieved from this Decision Support System can assist the company in providing recommendations for supplier determination, with the results of the Analytical Hierarchy Process calculation stating that the supplier whose value is higher than the other alternative supplier is CV Garuda Jaya.
\end{abstract}

Keywords: Decision Support System, Supplier Determination, Supplier, AHP 


\section{PENDAHULUAN}

\subsection{Latar Belakang}

Perusahaan ini mengalami kesulitan untuk memilih supplier karet komponen yang memiliki barang yang memiliki kualitas tinggi, harga terjangkau, stok yang melimpah dan jarak yang dekat untuk mendapatkan produk tersebut. Selain sulitnya untuk memilih supplier tersebut, kadangkala perusahaan karoseri sangat membutuhkan dalam jumlah yang sangat banyak dan menginginkan pengiriman karet komponen tersebut dikirimkan dalam waktu yang cepat sesuai dengan jadwal perakitan mobil di bengkel.

Dalam operasional kerja seperti yang di inginkan oleh perusahaan seperti pengiriman barang yang cepat, stok barang yang banyak dan memiliki kualitas barang bagus, Bintang Berlian Glass memiliki sebuah kasus dimana pemilihan karet komponen yang diberikan ke perusahaan karoseri memiliki kualitas yang rendah sehingga banyak terjadi komplain. Bintang Berlian Glass terdapat kelemahan dalam pemilihan supplier, karena perusahaan ini hanya menilai berdasarkan pada harga yang ditawarkan supplier dan kualitas yang dimiliki oleh barang secara subyektif. Dengan menggunakan sistem pendukung keputusan, maka pemilihan supplier akan lebih selektif dan tepat. Sistem pendukung keputusan ini menggunakan metode Analytical Hierarchy Process karena akan sangat cocok untuk mengambil keputusan yang multi-kriteria, ada berbagai kriteria sebagai parameter pengambilan keputusan yaitu mampu memberikan kualitas barang yang konsisten, ketersediaan barang, waktu pengiriman, kemudahan pengembalian, harga barang, pelayanan pelanggan, dan kualitas barang.

Berdasarkan masalah di atas, maka penulis tertarik untuk melakukan penelitian lebih lanjut dengan judul penelitian yaitu : "PERANCANGAN SISTEM PENDUKUNG KEPUTUSAN PEMILIHAN SUPPLIER KARET KOMPONEN KACA MOBIL DI BINTANG BERLIAN GLASS BANDUNG DENGAN MENGGUNAKAN METODE AHP (ANALYTICAL HIERARCHY PROCESS)", dengan harapan sistem yang dibangun dapat memudahkan perusahaan untuk mengambil keputusan untuk memilih supplier produk yang dipasarkan.

\subsection{Teori Pendukung}

Berdasarkan hasil pengolahan data dengan menggunakan metode Analytical Hierarchy Process (AHP) masing-masing bobot kriteria sebagai berikut: 
Kualitas (0.374), Harga (0.206), Ketepatan Pengiriman (0.119), Flexibilitas (0.134), Layanan Pelanggan (0.088) dan Jaminan dan Klaim (0.079. Hal ini mengandung arti bahwa kriteria kualitas merupakan kriteria yang terpenting diantara kriteria yang lain. Sedangkan hasil evaluasi suppliernya adalah bobot untuk SUPPLIER 1 sebesar 0.118, SUPPLIER 2 sebesar 0.224, SUPPLIER 3 sebesar 0.143, SUPPLIER 4 sebesar 0.137 dan SUPPLIER 5 sebesar 0.378. Berdasarkan hasil tersebut, maka SUPPLIER 5 memiliki bobot yang paling besar dan paling layak dijadikan supplier untuk perusahaan.(Sistem Pemgambilan Keputusan Pemilihan Supplier Bahan Baku Pada CV. Sinar Agung Perkasa Menggunakan AHP. - Penelusuran Google, n.d.)

Kriteria kualitas merupakan kriteria paling penting dalam pemilihan Supplier dengan presentase sebesar 39,50\%, berikutnya kriteria pengiriman dengan presentase nilai $20,56 \%$, berikutnya kriteria harga dengan presentase nilai $18,18 \%$ berikutnya kriteria responsibilitas dengan presentase nilai $14,66 \%$ dan yang terakhir kriteria pelayanan dengan presentase nilai 7,09\%.(Sistem Pendukung Keputusan Pemilihan Supplier Mnggunakan Metoda AHP Pada Transcoal Pacific Jakarta - Penelusuran Google, n.d.)

\subsubsection{Metode Analytical Hierarchy Process (AHP)}

Metode AHP (Analitycal Hierarchy Process) merupakan metode yang dikembangkan oleh Thomas L. Saaty sekitar tahun 1970, metode ini merupakan sebuah kerangka untuk pengambilan keputusan dengan efektif atas persoalan yang kompleks. Permasalahan pengambilan keputusan dapat menjadi kompleks karena adanya perlibatan beberapa tujuan maupun kriteria. Beberapa permasalahan yang dianggap kompleks seperti permasalahan, perencanaan, penentuan alternatif, penyusunan prioritas, pemilihan kebijaksanaan, alokasi sumber, penentuan kebutuhan, peramalah kebutuhan, perencanaan performance, optimasi, dan pemecahan konflik.(Vaidya \& Kumar, 2006).

Suatu masalah dapat dikatakan kompleks jika struktur permasalahannya tersebut tidak jelas dan juga tidak tersedianya data dan informasi statistik yang akurat, sehingga input atau masukan yang digunakan dalam menyelesaikan masalah ini adalah intuisi atau persepsi manusia. Tetapi intuisi ini tidak datang dari sembarang orang, intuisi ini harus datang dari orang - orang yang memahami dengan benar terhadap masalah apa 
yang ingin dipecahkannya. Ada 4 prinsip dasar yang digunakan untuk memecahkan persoalan AHP ini, yaitu membuat hierarki, penilaian kriteria dan alternatif, menentukan prioritas, dan mengkur konsistensi.

Secara spesifik, AHP cocok atau sesuai digunakan untuk mengatasi permasalahan pemilihan kandidat ataupun pengukuran prioritas yang memiliki beberapa sifat sebagai berikut :

1. Melibatkan kriteria-kriteria kualitatif yang sulit dikuantitatifkan secara eksak.

2. Masing-masing kriteria dapat memiliki sub-sub kriteria yang dapat dibentuk secara hierarki.

3. Penilaian dapat dilakukan oleh satu atau beberapa pengambil keputusan secara sekaligus.

4. Kandidat pilihan sudah tertentu dan terbatas jumlahnya.

Apabila suatu permasalahan pengambilan keputusan ingin diselesaikan dengan menggunakan metode AHP, permasalahan tersebut perlu dimodelkan dengan tiga hierarki umum, yakni tujuan, kriteria (termasuk sub - sub kriteria), dan alternatif. Konsep dasar dari AHP sebenarnya terletak dari penggunaan pairwise comparison matrix (matriks perbandingan berpasangan) untuk dapat mengahasilkan bobot relatif antar kriteria maupun alternatif. Suatu kriteria akan dibandingkan dengan kriteria lainnya dalam hal seberapa penting terhadap pencapaian tujuaannya. Untuk menentukan matriks perbandingan berpasangan dapat menggunakan nilai atau skala perbandingan yang biasa digunakan untuk mengukurnya yaitu dengan menggunakan skala 1 sampai 9. Skala pengukuran ini biasa dikenal dengan skala perbandingan.

\subsubsection{Tahapan Metode AHP}

Dalam menyelesaikan permasalahan dengan AHP ada beberapa prinsip yang harus dipahami, diantaranya adalah:

1. Membuat hierarki sistem yang kompleks bisa dipahami dengan memecahnya menjadi elemen-elemen pendukung, menyusun elemen secara hierarki dan menggabungkannya atau mensintesisnya.

2. Penilaian kriteria dan alternatif dilakukan dengan perbandingan berpasangan. Menurut Saaty, untuk berbagai persoalan, skala 1 sampai 9 adalah skala terbaik 
untuk mengekspresikan pendapat. Nilai dan definisi pendapat kualitatif dari skala perbandingan Saaty bisa diukur menggunakan tabel 1. analisis berikut.

Tabel 1. Skala Penilaian Perbandingan Pasangan

\begin{tabular}{cl}
\hline Intensitas Kepentingan & \multicolumn{1}{c}{ Keterangan } \\
\hline 1 & $\begin{array}{l}\text { Kedua elemen sama pentingnya } \\
\text { Elemen yang satu sedikit lebih }\end{array}$ \\
\hline 3 & $\begin{array}{l}\text { Elemen yang satu sedikit lebih penting } \\
\text { daripada elemen yang lainnya }\end{array}$ \\
\hline 5 & $\begin{array}{l}\text { Elemen yang satu lebih penting daripada } \\
\text { elemen yang lainnya }\end{array}$ \\
\hline 7 & $\begin{array}{l}\text { Satu elemen jelas lebih mutlak penting } \\
\text { daripada elemen lainnya }\end{array}$ \\
\hline \multirow{2}{*}{9} & $\begin{array}{l}\text { Satu elemen mutlak penting daripada } \\
\text { elemen lainnya }\end{array}$ \\
\hline $2,4,6,8$ & $\begin{array}{l}\text { Nilai-nilai antara dua nilai pertimbangan } \\
\text { yang berdekatan } \\
\text { Jika aktivitas i mendapat satu angka } \\
\text { dibandingkan dengan aktivitas j, maka } \mathrm{i} \\
\text { memiliki nilai kebalikannya dibandingkan } \\
\text { dengan aktivitas j, maka } \mathrm{i} \text { memiliki nilai } \\
\text { kebalikannya dibandingkan dengan i }\end{array}$ \\
\hline
\end{tabular}

3. Synthesis of priority (menentukan prioritas)

Untuk setiap kriteria dan alternatif, perlu dilakukan perbandingan berpasangan (Pairwise Comparisons). Nilai-nilai perbandingan relatif dari seluruh alternatif kriteria bisa disesuaikan dengan judgement yang telah ditentukan untuk menghasilkan bobot dan prioritas. Bobot dan prioritas dihitung dengan memanipulasi matriks atau melalui penyelesaian persamaan matematika.

4. Logical Consistency (Konsistensi Logis)

Konsistensi memiliki dua makna. Pertama, objek-objek yang serupa bisa dikelompokkan sesuai dengan keseragaman dan relevansi. Kedua, menyangkut tingkat hubungan antar objek yang didasarkan pada kriteria tertentu.

\subsubsection{Rumus AHP}

Prosedur atau langkah-langkah dalam metode AHP meliputi: Mendefinisikan masalah dan menentukan solusi yang diinginkan, lalu menyusun hierarki dari 
permasalahan yang dihadapi. Penyusunan hierarki adalah dengan menetapkan tujuan yang merupakan sasaran sistem secara keseluruhan pada level teratas.

1. Menetukan prioritas elemen

a. Langkah pertama dalam menentukan prioritas elemen adalah membuat perbandingan pasangan, yaitu membandingkan elemen secara berpasangan sesuai kriteria yang diberikan.

b. Matriks perbandingan berpasangan diisi menggunakan bilangan untuk merepresentasikan kepentingan relatif dari suatu elemen terhadap elemen lainnya.

2. Sintesis

Pertimbangan-pertimbangan terhadap perbandingan berpasangan di sintesis untuk memperoleh keseluruhan prioritas. Hal-hal yang dilakukan dalam langkah ini adalah :

a. Menjumlahkan nilai-nilai dari setiap kolom pada matriks membagi setiap nilai dari kolom dengan total kolom yang bersangkutan untuk memperoleh normalisasi matriks.

b. Menjumlahkan nilai-nilai dari setiap baris dan membaginya dengan jumlah elemen untuk mendapatkan nilai rata-rata.

3. Mengukur konsistensi

Dalam pembuatan keputusan, penting untuk mengetahui seberapa baik konsistensi yang ada karena kita tidak menginginkan keputusan berdasarkan pertimbangan dengan konsistensi yang rendah. Hal-hal yang dilakukan dalam langkah ini adalah :

a. Kalikan setiap nilai pada kolom pertama dengan prioritas relatif elemen pertama,

b. Nilai pada kolom kedua dengan prioritas relatif elemen kedua, dan seterusnya jumlahkan setiap baris hasil dari penjumlahan baris dibagi dengan elemen prioritas relatif yang bersangkutan jumlahkan hasil bagi di atas dengan banyaknya elemen yang ada, hasilnya disebut $(\boldsymbol{\lambda})$ maks.

c. Hitung Consistency Index (CI) dengan rumus berikut:

$\mathrm{CI}=(\lambda \max -\mathrm{n}) / \mathrm{n}$ 


\section{Rumus Consistency Index}

Dimana $\mathrm{n}=$ banyaknya elemen

d. Hitung Rasio Konsistensi/ Consistency Ratio (CR) dengan rumus: $\mathrm{CR}=\mathrm{CI} / \mathrm{IR}$

$$
\begin{aligned}
& \text { Dimana } \mathrm{CR}=\text { Consistency Ratio } \\
& \mathrm{CI}=\text { Consistency Index } \\
& \mathrm{IR}=\text { Indeks Random Consistency }
\end{aligned}
$$

e. Memeriksa konsistensi hierarki. Jika nilainya lebih dari $10 \%$, maka penilaian data judgement harus diperbaiki. Namun jika rasio konsistensi (CI/IR) kurang atau sama dengan 0,1 maka hasil perhitungan bisa di nyatakan benar. Berikut daftar Indeks Random Konsistensi (IR) ditunjukan pada tabel 2 di bawah.(Vaidya \& Kumar, 2006)

Tabel 2. Indeks Random Konsistensi

\begin{tabular}{cc}
\hline Ukuran Matriks & Nilai IR \\
\hline 1,2 & 0,00 \\
\hline 3 & 0,58 \\
\hline 4 & 0,90 \\
\hline 5 & 1,12 \\
\hline 6 & 1,24 \\
\hline 7 & 1,32 \\
\hline 8 & 1,41 \\
\hline 9 & 1,45 \\
\hline 10 & 1,49 \\
\hline 11 & 1,51 \\
\hline 12 & 1,48 \\
\hline 13 & 1,56 \\
\hline 14 & 1,57 \\
\hline 15 & 1,59
\end{tabular}

\section{METODE PENELITIAN}

\subsection{Teknik Pengumpulan Data}

Dalam penelitian ini digunakan teknik pengumpulan data yang dilakukan dengan beberapa tahap, diantaranya : 
1. Observasi, yaitu melihat dan mengamati secara langsung proses pengolahan data yang ada.

2. Wawancara, yaitu mengumpulkan data yang dilakukan dengan cara melakukan tanya jawab secara langsung kepada pihak-pihak yang terkait guna mendapatkan keterangan-keterangan yang diperlukan.

3. Studi pustaka, yaitu membaca buku-buku atau mencari referensi dari internet yang terkait secara langsung maupun tidak langsung untuk mengetahui secara teoritis permasalahan yang sedang dihadapi

\subsection{Metode Pengembangan Perangkat Lunak}

Metode Pengembangan Sistem yaitu SDLC (System Development Life Cycle) atau Waterfall merupakan suatu bentuk yang digunakan untuk menggambarkan tahapan dan langkah-langkah didalam tahapan tersebut dalam proses pengembangannya. Tahapan tersebut terdiri dari:

1. System Engineering, merupakan bagian awal dari pengerjaan suatu proyek perangkat lunak. Dimulai dengan mempersiapkan segala hal yang diperlukan dalam pelaksanaan proyek.

2. Analysis, merupakan tahapan dimana System Engineering menganalisis segala hal yang ada pada pembuatan proyek atau pengembangan perangkat lunak yang bertujuan untuk memahami sistem yang ada, mengidentifikasi masalah dan mencari solusinya.

3. Design, tahapan ini merupakan tahap penerjemah dari keperluan atau data yang telah dianalisis ke dalam bentuk yang mudah dimengerti oleh pemakai (user).

4. Coding, yaitu menerjemahkan data yang dirancang ke dalam bahasa pemrograman yang telah ditentukan.

5. Testing, merupakan uji coba terhadap sistem atau program setelah selesai dibuat.

6. Maintenance, yaitu penerapan sistem secara keseluruhan disertai pemeliharaan jika terjadi perubahan struktur, baik dari segi software maupun hardware.(Rosa Ariani Sukamto - Google Cendekia, n.d.) 


\section{HASIL DAN PEMBAHASAN}

\subsection{Menentukan Kriteria}

Dalam metode AHP terdapat kriteria yang dibutuhkan untuk proses perhitungan nantinya. Dalam kasus ini ada tujuh kriteria yang akan digunakan untuk proses pengambilan keputusan menentukan supplier yaitu, kualitas barang yang konsisten, ketersediaan barang, waktu pengiriman, kemudahan pengembalian, harga barang, pelayanan pelanggan, dan kualitas barang. Rating kecocokan setiap alternatif penilaian pada setiap kriteria yaitu berupa nilai dari 1 sampai dengan 9. Untuk lebih jelasnya bisa dilihat tabel 3 preferensi tiap kriteria berikut ini:

Tabel 1. Preferensi Bobot Untuk Kriteria Dan Alternatif

\begin{tabular}{cc} 
Bobot & Keterangan Bobot \\
\hline 1 & Mutlak Sangat Penting \\
\hline 2 & Mendekati Mutlak Dari \\
\hline 3 & Sangat Penting Dari \\
\hline 4 & Mendekati Sangat Penting Dari \\
\hline 5 & Lebih Penting Dari \\
\hline 6 & Mendekati Lebih Penting Dari \\
\hline 7 & Sedikit Lebih Penting Dari \\
\hline 8 & Mendekati Sedikit Lebih \\
& Penting Dari \\
\hline 9 & Sama Penting Dengan
\end{tabular}

Setelah itu diperlukan kriteria - kriteria dan bobot dalam melakukan perhitungan sehingga akan dapat alternatif terbaik. Tabel 4. di bawah merupakan tabel kriteria yang telah dibuat:

Tabel 4. Kriteria

\begin{tabular}{cc}
\hline Kriteria & Keterangan \\
\hline C1 & Kualitas barang yang konsisten \\
\hline C2 & Ketersediaan barang \\
\hline C3 & Waktu pengiriman \\
\hline C4 & Kemudahan pengembalian \\
\hline C5 & Harga barang \\
\hline C6 & Pelayanan pelanggan \\
\hline C7 & Kualitas barang \\
\hline
\end{tabular}

Berikut adalah tabel alternatif yang ditunjukan pada tabel 5 berisikan variablevariabel penilaian alternatif. 
Tabel 2. Alternatif

\begin{tabular}{cc}
\hline Alernatif & Keterangan \\
\hline A1 & CV Garuda Jaya \\
\hline A2 & CV Sulaiman Putra \\
\hline A3 & CV Karya Sekawan \\
\hline A4 & PT Karya Putra Sangkuriang \\
\hline A5 & CV Hutan Karet \\
\hline
\end{tabular}

\subsection{Penilaian Bobot Kriteria}

Perhitungan pembobotan penilaian kriteria dilakukan dengan perbandingan berpasangan untuk semua kriteria. Maka selanjutnya melakukan penilaian preferensi bobot tiap kriteria pada tiap kriteria.

Nilai eigen maksimum ( $\lambda$ maksimum) dapat dicari dengan cara menjumlahkan hasil perkalian jumlah kolom dengan vektor eigen. Maka nilai eigen maksimum yang dapat diperoleh yaitu:

$$
\begin{aligned}
& \propto \max =7,60 \\
& \text { CI } \quad=\frac{\propto \max -n}{n-1} \\
&=0,10
\end{aligned}
$$

Untuk $\mathrm{n}=7, \mathrm{RI}=1,320$ (tabel Saaty), maka:

$$
\begin{aligned}
\mathrm{CR} & =\mathrm{CI} / \mathrm{RI} \\
& =0.077
\end{aligned}
$$

Nilai 0,077 ini menyatakan bahwa rasio konsistensi dari hasil penilaian pembandingan di atas mempunyai rasio 7\%. Sehingga penilaian di atas dapat diterima karena lebih kecil dari 10\%.(Saaty, 2008)

\subsection{Penilaian Alternatif Terhadap Kriteria Konsistensi Kualitas}

Berikut tabel pembobotan penilaian dan perbandingan berpasangan alternative terhadap kriteria: 
Tabel 6. Matriks Alternatif Terhadap Kriteria Konsistensi Kualitas

\begin{tabular}{cccccc}
\hline & $\begin{array}{c}\text { CV } \\
\text { Garuda Jaya }\end{array}$ & $\begin{array}{c}\text { CV } \\
\text { Sulaiman Putra }\end{array}$ & $\begin{array}{c}\text { CV } \\
\text { Karya } \\
\text { Sekawan }\end{array}$ & $\begin{array}{c}\text { PT Karya Putra } \\
\text { Sangkuriang }\end{array}$ & $\begin{array}{c}\text { CV } \\
\text { Hutan Karet }\end{array}$ \\
\hline $\begin{array}{c}\text { CV Garuda } \\
\text { Jaya }\end{array}$ & 1,00 & 7,00 & 3,00 & 3,00 & 7,00 \\
\hline $\begin{array}{c}\text { CV Sulaiman } \\
\text { Jaya }\end{array}$ & 0,14 & 1,00 & 0,33 & 0,33 & 3,00 \\
\hline $\begin{array}{c}\text { CV Karya } \\
\text { Sekawan }\end{array}$ & 0,33 & 3,00 & 1,00 & 0,33 & 3,00 \\
\hline $\begin{array}{c}\text { PT Karya Putra } \\
\text { Sangkuriang }\end{array}$ & 0,33 & 3,00 & 3,00 & 1,00 & 1,00 \\
\hline $\begin{array}{c}\text { CV Hutan } \\
\text { Karet }\end{array}$ & 0,14 & 3,00 & 0,33 & 0,33 & 14,33 \\
\hline$\sum$ & 1,95 & 17,00 & 7,67 & 5,00 & \\
\hline
\end{tabular}

Berikut adalah tabel 7 Matriks Alternatif Terhadap Kriteria Konsistensi Kualitas, jika sudah memasukan bobot nilai maka lakukan tahapan seperti di bawah ini:

Tabel 7. Normalisasi Matriks Alternatif Terhadap Kriteria Konsistensi Kualitas

\begin{tabular}{ccccccc}
\hline $\begin{array}{c}\text { CV } \\
\text { Garuda Jaya }\end{array}$ & $\begin{array}{c}\text { CV } \\
\text { Sulaiman } \\
\text { Putra }\end{array}$ & $\begin{array}{c}\text { CV } \\
\text { Karya } \\
\text { Sekawan }\end{array}$ & $\begin{array}{c}\text { PT Karya } \\
\text { Putra } \\
\text { Sangkuriang }\end{array}$ & $\begin{array}{c}\text { CV } \\
\text { Hutan Karet }\end{array}$ & $\sum$ & $\begin{array}{c}\text { Eigen } \\
\text { Faktor }\end{array}$ \\
\hline 0,51 & 0,41 & 0,39 & 0,60 & 0,49 & 2,40 & 0,481 \\
\hline 0,07 & 0,06 & 0,04 & 0,07 & 0,02 & 0,27 & 0,053 \\
\hline 0,17 & 0,18 & 0,13 & 0,07 & 0,21 & 0,75 & 0,151 \\
\hline 0,17 & 0,18 & 0,39 & 0,20 & 0,21 & 1,15 & 0,230 \\
\hline 0,07 & 0,18 & 0,04 & 0,07 & 0,07 & 0,43 & 0,086 \\
\hline
\end{tabular}

\section{Mengukur Konsistensi Kriteria Konsistensi}

Nilai eigen maksimum ( $\lambda$ maksimum) dapat dicari dengan cara menjumlahkan hasil perkalian jumlah kolom dengan vektor eigen. Maka nilai eigen maksimum yang dapat diperoleh yaitu:

$$
\begin{aligned}
\propto \max & =5,37 \\
\mathrm{CI} & =\frac{\propto \max -\mathrm{n}}{\mathrm{n}-1} \\
& =(5.37-5) /(5-1) \\
& =0.09
\end{aligned}
$$


Untuk $\mathrm{n}=5, \mathrm{RI}=1,120$ (Tabel Saaty), maka:

$$
\begin{aligned}
\mathrm{CR} & =\mathrm{CI} / \mathrm{RI} \\
& =0.09 / 1,120 \\
& =0.080
\end{aligned}
$$

Nilai 0,080 ini menyatakan bahwa rasio konsistensi dari hasil penilaian pembandingan di atas mempunyai rasio $8 \%$. Sehingga penilaian di atas dapat diterima karena lebih kecil dari 10\%.(Saaty, 2008)

\subsection{Penilaian Alternatif Terhadap Kriteria Ketersediaan Barang}

Berikut tabel pembobotan penilaian dan perbandingan berpasangan alternative terhadap kriteria:

Tabel 8. Matriks Alternatif Terhadap Kriteria Ketersediaan Barang

\begin{tabular}{cccccc}
\hline $\begin{array}{c}\text { C2 } \\
\begin{array}{c}\text { Ketersediaan } \\
\text { barang) }\end{array}\end{array}$ & $\begin{array}{c}\text { CV } \\
\text { Garuda Jaya }\end{array}$ & $\begin{array}{c}\text { CV } \\
\text { Sulaiman Putra }\end{array}$ & $\begin{array}{c}\text { CV } \\
\text { Karya } \\
\text { Sekawan }\end{array}$ & $\begin{array}{c}\text { PT Karya Putra } \\
\text { Sangkuriang }\end{array}$ & $\begin{array}{c}\text { CV } \\
\text { Hutan Karet }\end{array}$ \\
\hline $\begin{array}{c}\text { CV Garuda } \\
\text { Jaya }\end{array}$ & 1,00 & 3,00 & 0,33 & 0,20 & 3,00 \\
\hline $\begin{array}{c}\text { CV Sulaiman } \\
\text { Putra }\end{array}$ & 0,33 & 1,00 & 0,20 & 0,14 & 0,33 \\
\hline $\begin{array}{c}\text { CV Karya } \\
\text { Sekawan }\end{array}$ & 3,00 & 5,00 & 1,00 & 0,33 & 3,00 \\
\hline $\begin{array}{c}\text { PT Karya Putra } \\
\text { Sangkuriang }\end{array}$ & 5,00 & 7,00 & 3,00 & 1,00 & 1,00 \\
\hline $\begin{array}{c}\text { CV Hutan } \\
\text { Karet }\end{array}$ & 0,33 & 3,00 & 0,33 & 0,20 & 12,33 \\
\hline$\sum$ & 9,67 & 19,00 & 4,87 & 1,88 & \\
\hline
\end{tabular}

Berikut adalah tabel 9 Matriks Alternatif Terhadap Kriteria Ketersediaan Barang, jika sudah memasukan bobot nilai maka lakukan tahapan seperti di bawah ini:

Tabel 9. Normalisasi Matriks Alternatif Terhadap Kriteria Ketersediaan Barang

\begin{tabular}{ccccccc}
\hline $\begin{array}{c}\text { CV } \\
\text { Garuda Jaya }\end{array}$ & $\begin{array}{c}\text { CV } \\
\text { Sulaiman } \\
\text { Putra }\end{array}$ & $\begin{array}{c}\text { CV } \\
\text { Karya } \\
\text { Sekawan }\end{array}$ & $\begin{array}{c}\text { PT Karya } \\
\text { Putra } \\
\text { Sangkuriang }\end{array}$ & $\begin{array}{c}\text { CV } \\
\text { Hutan Karet }\end{array}$ & $\sum$ & $\begin{array}{c}\text { Eigen } \\
\text { Faktor }\end{array}$ \\
\hline 0,10 & 0,16 & 0,07 & 0,11 & 0,24 & 0,68 & 0,136 \\
\hline 0,03 & 0,05 & 0,04 & 0,08 & 0,03 & 0,23 & 0,046 \\
\hline 0,31 & 0,26 & 0,21 & 0,18 & 0,24 & 1,20 & 0,240 \\
\hline 0,52 & 0,37 & 0,62 & 0,53 & 0,41 & 2,44 & 0,488 \\
\hline 0,03 & 0,16 & 0,07 & 0,11 & 0,08 & 0,45 & 0,090 \\
\hline
\end{tabular}


Setelah melakukan penjumlahan maka dihasilkan hasil normalisasi matriks seperti tabel 9 Normalisasi Matriks Alternatif Terhadap Kriteria Ketersediaan Barang. Mengukur Konsistensi Kriteria Ketersediaan Barang

Nilai eigen maksimum ( $\lambda$ maksimum) dapat dicari dengan cara menjumlahkan hasil perkalian jumlah kolom dengan vektor eigen. Maka nilai eigen maksimum yang dapat diperoleh yaitu:

$$
\begin{aligned}
\propto \max & =5,38 \\
\mathrm{CI} \quad & =\frac{\propto \max -\mathrm{n}}{\mathrm{n}-1} \\
& =(5.38-5) /(5-1) \\
& =0.09
\end{aligned}
$$

Untuk $\mathrm{n}=5, \mathrm{RI}=1,120$ (Tabel Saaty), maka:

$$
\begin{aligned}
\text { CR } & =\mathrm{CI} / \mathrm{RI} \\
= & 0.09 / 1,120 \\
= & 0.08
\end{aligned}
$$

Nilai 0,08 ini menyatakan bahwa rasio konsistensi dari hasil penilaian pembandingan di atas mempunyai rasio $8 \%$. Sehingga penilaian di atas dapat diterima karena lebih kecil dari 10\%.(Saaty, 2008)

\subsection{Penilaian Alternatif Terhadap Kriteria Waktu Pengiriman}

Berikut tabel pembobotan penilaian dan perbandingan berpasangan alternative terhadap kriteria:

Tabel 10. Matriks Alternatif Terhadap Kriteria Waktu Pengiriman

\begin{tabular}{cccccc}
\hline $\begin{array}{c}\text { C3 (Waktu } \\
\text { pengiriman) }\end{array}$ & $\begin{array}{c}\mathrm{CV} \\
\text { Garuda Jaya }\end{array}$ & $\begin{array}{c}\mathrm{CV} \\
\text { Sulaiman Putra }\end{array}$ & $\begin{array}{c}\mathrm{CV} \\
\text { Karya } \\
\text { Sekawan }\end{array}$ & $\begin{array}{c}\text { PT Karya Putra } \\
\text { Sangkuriang }\end{array}$ & $\begin{array}{c}\mathrm{CV} \\
\text { Hutan Karet }\end{array}$ \\
\hline $\begin{array}{c}\text { CV Garuda } \\
\text { Jaya }\end{array}$ & 1,00 & 3,00 & 0,50 & 5,00 & 3,00 \\
\hline $\begin{array}{c}\text { CV Sulaiman } \\
\text { Putra }\end{array}$ & 0,33 & 1,00 & 0,20 & 0,33 & 0,33 \\
\hline $\begin{array}{c}\text { CV Karya } \\
\text { Sekawan }\end{array}$ & 2,00 & 5,00 & 1,00 & 3,00 & 0,33 \\
\hline $\begin{array}{c}\text { PT Karya Putra } \\
\text { Sangkuriang }\end{array}$ & 0,20 & 3,00 & 0,33 & 1,00 & 1,00 \\
\hline $\begin{array}{c}\text { CV Hutan } \\
\text { Karet }\end{array}$ & 0,33 & 3,00 & 0,50 & 3,00 & 6,67 \\
\hline$\sum$ & 3,87 & 15,00 & 2,53 & 12,33 & 60 \\
\hline
\end{tabular}


Berikut adalah tabel 11. Matriks Alternatif Terhadap Kriteria Waktu Pengiriman, jika sudah memasukan bobot nilai maka lakukan tahapan seperti di bawah ini:

Tabel 11. Normalisasi Matriks Alternatif Terhadap Kriteria Waktu Pengiriman

\begin{tabular}{ccccccc}
\hline $\begin{array}{c}\text { CV } \\
\text { Garuda Jaya }\end{array}$ & $\begin{array}{c}\text { CV } \\
\text { Sulaiman } \\
\text { Putra }\end{array}$ & $\begin{array}{c}\text { CV } \\
\text { Karya } \\
\text { Sekawan }\end{array}$ & $\begin{array}{c}\text { PT Karya } \\
\text { Putra } \\
\text { Sangkuriang }\end{array}$ & $\begin{array}{c}\text { CV } \\
\text { Hutan Karet }\end{array}$ & $\sum$ & $\begin{array}{c}\text { Eigen } \\
\text { Faktor }\end{array}$ \\
\hline 0,26 & 0,20 & 0,20 & 0,41 & 0,45 & 1,51 & 0,302 \\
\hline 0,09 & 0,07 & 0,08 & 0,03 & 0,05 & 0,31 & 0,062 \\
\hline 0,52 & 0,33 & 0,39 & 0,24 & 0,30 & 1,79 & 0,358 \\
\hline 0,05 & 0,20 & 0,13 & 0,08 & 0,05 & 0,51 & 0,103 \\
\hline 0,09 & 0,20 & 0,20 & 0,24 & 0,15 & 0,88 & 0,175 \\
\hline
\end{tabular}

Setelah melakukan penjumlahan maka dihasilkan hasil normalisasi matriks seperti tabel 11 di atas.

\section{Mengukur Konsistensi Kriteria Waktu Pengiriman}

Nilai eigen maksimum ( $\lambda$ maksimum) dapat dicari dengan cara menjumlahkan hasil perkalian jumlah kolom dengan vektor eigen. Maka nilai eigen maksimum yang dapat diperoleh yaitu:

$$
\begin{aligned}
\propto \max & =5,43 \\
\mathrm{CI} & =\frac{\propto \max -\mathrm{n}}{\mathrm{n}-1} \\
& =(5.43-5) /(5-1) \\
& =0.11
\end{aligned}
$$

Untuk $\mathrm{n}=5, \mathrm{RI}=1,120$ (Tabel Saaty), maka:

$$
\begin{aligned}
\mathrm{CR} & =\mathrm{CI} / \mathrm{RI} \\
& =0.11 / 1.120 \\
& =0.09
\end{aligned}
$$

Nilai 0,09 ini menyatakan bahwa rasio konsistensi dari hasil penilaian pembandingan di atas mempunyai rasio 9\%. Sehingga penilaian di atas dapat diterima karena lebih kecil dari 10\%.(Saaty, 2008) 


\subsection{Penilaian Alternatif Terhadap Kriteria Kualitas Barang}

Berikut tabel pembobotan penilaian dan perbandingan berpasangan alternative terhadap kriteria:

Tabel 12. Matriks Alternatif Terhadap Kriteria Kualitas Barang

\begin{tabular}{|c|c|c|c|c|c|}
\hline $\begin{array}{l}\text { C4 (Kualitas } \\
\text { Barang) }\end{array}$ & $\begin{array}{c}\text { CV } \\
\text { Garuda Jaya }\end{array}$ & $\begin{array}{c}\text { CV } \\
\text { Sulaiman Putra }\end{array}$ & $\begin{array}{c}\text { CV } \\
\text { Karya } \\
\text { Sekawan }\end{array}$ & $\begin{array}{c}\text { PT Karya Putra } \\
\text { Sangkuriang }\end{array}$ & $\begin{array}{c}\text { CV } \\
\text { Hutan Karet }\end{array}$ \\
\hline $\begin{array}{l}\text { CV Garuda } \\
\text { Jaya }\end{array}$ & 1,00 & 7,00 & 3,00 & 0,50 & 7,00 \\
\hline $\begin{array}{l}\text { CV Sulaiman } \\
\text { Putra }\end{array}$ & 0,14 & 1,00 & 0,20 & 0,14 & 2,00 \\
\hline $\begin{array}{l}\text { CV Karya } \\
\text { Sekawan }\end{array}$ & 0,33 & 5,00 & 1,00 & 0,20 & 5,00 \\
\hline $\begin{array}{l}\text { PT Karya Putra } \\
\text { Sangkuriang }\end{array}$ & 2,00 & 7,00 & 5,00 & 1,00 & 7,00 \\
\hline $\begin{array}{l}\text { CV Hutan } \\
\text { Karet }\end{array}$ & 0,14 & 0,50 & 0,20 & 0,14 & 1,00 \\
\hline$\sum$ & 3,62 & 20,50 & 9,40 & 1,99 & 22,00 \\
\hline
\end{tabular}

Berikut adalah tabel 13 Matriks Alternatif Terhadap Kriteria Kualitas Barang, jika sudah memasukankan bobot nilai maka lakukan tahapan seperti di bawah ini:

Tabel 13. Normalisasi Matriks Alternatif Terhadap Kriteria Kualitas Barang

\begin{tabular}{ccccccc}
\hline $\begin{array}{c}\text { CV } \\
\text { Garuda Jaya }\end{array}$ & $\begin{array}{c}\text { CV } \\
\text { Sulaiman } \\
\text { Putra }\end{array}$ & $\begin{array}{c}\text { CV } \\
\text { Karya } \\
\text { Sekawan }\end{array}$ & $\begin{array}{c}\text { PT Karya } \\
\text { Putra } \\
\text { Sangkuriang }\end{array}$ & $\begin{array}{c}\text { CV } \\
\text { Hutan Karet }\end{array}$ & $\sum$ & $\begin{array}{c}\text { Eigen } \\
\text { Faktor }\end{array}$ \\
\hline 0,28 & 0,34 & 0,32 & 0,25 & 0,32 & 1,51 & 0,301 \\
\hline 0,04 & 0,05 & 0,02 & 0,07 & 0,09 & 0,27 & 0,054 \\
\hline 0,09 & 0,24 & 0,11 & 0,10 & 0,23 & 0,77 & 0,154 \\
\hline 0,55 & 0,34 & 0,53 & 0,50 & 0,32 & 2,25 & 0,450 \\
\hline 0,04 & 0,02 & 0,02 & 0,07 & 0,05 & 0,20 & 0,041 \\
\hline
\end{tabular}

Setelah melakukan penjumlahan maka dihasilkan hasil normalisasi matriks seperti Tabel 13.

\section{Mengukur Konsistensi Kriteria Kualitas Barang}

Nilai eigen maksimum ( $\lambda$ maksimum) dapat dicari dengan cara menjumlahkan hasil perkalian jumlah kolom dengan vektor eigen. Maka nilai eigen maksimum yang dapat diperoleh yaitu: 


$$
\begin{aligned}
\propto \max & =5,44 \\
\mathrm{CI} & =\frac{\propto \max -\mathrm{n}}{\mathrm{n}-1} \\
& =(5.44-5) /(5-1) \\
& =0.11
\end{aligned}
$$

Untuk $\mathrm{n}=5, \mathrm{RI}=1,120$ (Tabel Saaty), maka:

$\mathrm{CR} \quad=\mathrm{CI} / \mathrm{RI}$

$$
\begin{aligned}
& =0.11 / 1.120 \\
& =0.09
\end{aligned}
$$

Nilai 0,09 ini menyatakan bahwa rasio konsistensi dari hasil penilaian

\begin{tabular}{|c|c|c|c|c|c|}
\hline $\begin{array}{c}\text { C5 } \\
\text { (Kemudahan } \\
\text { Pengembalian) }\end{array}$ & $\begin{array}{c}\text { CV } \\
\text { Garuda Jaya }\end{array}$ & $\begin{array}{c}\text { CV } \\
\text { Sulaiman Putra }\end{array}$ & $\begin{array}{c}\text { CV } \\
\text { Karya } \\
\text { Sekawan } \\
\end{array}$ & $\begin{array}{l}\text { PT Karya Putra } \\
\text { Sangkuriang }\end{array}$ & $\begin{array}{c}\text { CV } \\
\text { Hutan Karet }\end{array}$ \\
\hline $\begin{array}{l}\text { CV Garuda } \\
\text { Jaya }\end{array}$ & 1,00 & 7,00 & 1,00 & 3,00 & 7,00 \\
\hline $\begin{array}{l}\text { CV Sulaiman } \\
\text { Putra }\end{array}$ & 0,14 & 1,00 & 0,20 & 0,33 & 3,00 \\
\hline $\begin{array}{l}\text { CV Karya } \\
\text { Sekawan }\end{array}$ & 1,00 & 5,00 & 1,00 & 5,00 & 4,00 \\
\hline $\begin{array}{c}\text { PT Karya Putra } \\
\text { Sangkuriang }\end{array}$ & 0,33 & 3,00 & 0,20 & 1,00 & 3,00 \\
\hline $\begin{array}{l}\text { CV Hutan } \\
\text { Karet }\end{array}$ & 0,14 & 0,33 & 0,25 & 0,33 & 1,00 \\
\hline$\sum$ & 2,62 & 16,33 & 2,65 & 9,67 & 18,00 \\
\hline
\end{tabular}
pembandingan di atas mempunyai rasio 9\%. Sehingga penilaian di atas dapat diterima karena lebih kecil dari 10\%.(Saaty, 2008)

\subsection{Penilaian Alternatif Terhadap Kriteria Kemudahan Pengembalian}

Berikut tabel pembobotan penilaian dan perbandingan berpasangan alternative terhadap kriteria:

Tabel 14. Matriks Alternatif Terhadap Kriteria Kemudahan Pengembalian

Berikut adalah tabel 15. Matriks Alternatif Terhadap Kriteria Kemudahan Pengembalian, jika sudah memasukan bobot nilai maka lakukan tahapan seperti di bawah ini: 
Tabel 15. Normalisasi Matriks Alternatif Terhadap Kriteria Kemudahan Pengembalian

\begin{tabular}{ccccccc}
\hline $\begin{array}{c}\text { CV } \\
\text { Garuda Jaya }\end{array}$ & $\begin{array}{c}\text { CV } \\
\text { Sulaiman } \\
\text { Putra }\end{array}$ & $\begin{array}{c}\text { CV } \\
\text { Karya } \\
\text { Sekawan }\end{array}$ & $\begin{array}{c}\text { PT Karya } \\
\text { Putra } \\
\text { Sangkuriang }\end{array}$ & $\begin{array}{c}\text { CV } \\
\text { Hutan Karet }\end{array}$ & $\sum$ & $\begin{array}{c}\text { Eigen } \\
\text { Faktor }\end{array}$ \\
\hline 0,38 & 0,43 & 0,38 & 0,31 & 0,39 & 1,89 & 0,377 \\
\hline 0,05 & 0,06 & 0,08 & 0,03 & 0,17 & 0,39 & 0,078 \\
\hline 0,38 & 0,31 & 0,38 & 0,52 & 0,22 & 1,80 & 0,361 \\
\hline 0,13 & 0,18 & 0,08 & 0,10 & 0,17 & 0,66 & 0,131 \\
\hline 0,05 & 0,02 & 0,09 & 0,03 & 0,06 & 0,26 & 0,052 \\
\hline
\end{tabular}

Setelah melakukan penjumlahan maka dihasilkan hasil normalisasi matriks seperti Tabel 15 di atas.

\section{Mengukur Konsistensi Kriteria Kemudahan Pengembalian}

Nilai eigen maksimum ( $\lambda$ maksimum) dapat dicari dengan cara menjumlahkan hasil perkalian jumlah kolom dengan vektor eigen. Maka nilai eigen maksimum yang dapat diperoleh yaitu:

$$
\begin{array}{lc}
\propto \max & =5,43 \\
\text { CI } & =\underline{\propto \max -n} \\
& \mathrm{n}-1 \\
= & (5.43-5) /(5-1) \\
& =0.10
\end{array}
$$

Untuk $\mathrm{n}=5, \mathrm{RI}=1,120$ (Tabel Saaty), maka:

$$
\begin{aligned}
\mathrm{CR} & =\mathrm{CI} / \mathrm{RI} \\
& =0.10 / 1.120 \\
& =0.09
\end{aligned}
$$

Nilai 0,09 ini menyatakan bahwa rasio konsistensi dari hasil penilaian pembandingan $\mathrm{di}$ atas mempunyai rasio 9\%. Sehingga penilaian di atas dapat diterima karena lebih kecil dari 10\%.(Saaty, 2008)

\subsection{Penilaian Alternatif Terhadap Kriteria Harga Barang}

Berikut tabel pembobotan penilaian dan perbandingan berpasangan alternative terhadap kriteria: 
Tabel 16. Matriks Alternatif Terhadap Kriteria Harga Barang

\begin{tabular}{|c|c|c|c|c|c|}
\hline $\begin{array}{l}\text { C6 (Harga } \\
\text { Barang) }\end{array}$ & $\begin{array}{c}\text { CV } \\
\text { Garuda Jaya }\end{array}$ & $\begin{array}{c}\text { CV } \\
\text { Sulaiman Putra }\end{array}$ & $\begin{array}{c}\text { CV } \\
\text { Karya } \\
\text { Sekawan }\end{array}$ & $\begin{array}{c}\text { PT Karya Putra } \\
\text { Sangkuriang }\end{array}$ & $\begin{array}{c}\text { CV } \\
\text { Hutan Karet }\end{array}$ \\
\hline $\begin{array}{l}\text { CV Garuda } \\
\text { Jaya }\end{array}$ & 1,00 & 7,00 & 3,00 & 5,00 & 3,00 \\
\hline $\begin{array}{l}\text { CV Sulaiman } \\
\text { Putra }\end{array}$ & 0,14 & 1,00 & 0,20 & 0,33 & 0,33 \\
\hline $\begin{array}{l}\text { CV Karya } \\
\text { Sekawan }\end{array}$ & 0,33 & 5,00 & 1,00 & 3,00 & 3,00 \\
\hline $\begin{array}{l}\text { PT Karya Putra } \\
\text { Sangkuriang }\end{array}$ & 0,20 & 3,00 & 0,33 & 1,00 & 0,33 \\
\hline $\begin{array}{l}\text { CV Hutan } \\
\text { Karet }\end{array}$ & 0,33 & 3,00 & 0,33 & 3,00 & 1,00 \\
\hline$\sum$ & 2,01 & 19,00 & 4,87 & 12,33 & 7,67 \\
\hline
\end{tabular}

Berikut adalah tabel 17. Matriks Alternatif Terhadap Kriteria Harga Barang, jika sudah memasukan bobot nilai maka lakukan tahapan seperti di bawah ini:

Tabel 17. Normalisasi Matriks Alternatif Terhadap Kriteria Harga Barang

\begin{tabular}{ccccccc}
\hline $\begin{array}{c}\text { CV } \\
\text { Garuda Jaya }\end{array}$ & $\begin{array}{c}\text { CV } \\
\text { Sulaiman } \\
\text { Putra }\end{array}$ & $\begin{array}{c}\text { CV } \\
\text { Karya } \\
\text { Sekawan }\end{array}$ & $\begin{array}{c}\text { PT Karya } \\
\text { Putra } \\
\text { Sangkuriang }\end{array}$ & $\begin{array}{c}\text { CV } \\
\text { Hutan Karet }\end{array}$ & $\sum$ & $\begin{array}{c}\text { Eigen } \\
\text { Faktor }\end{array}$ \\
\hline 0,50 & 0,37 & 0,62 & 0,41 & 0,39 & 2,28 & 0,456 \\
\hline 0,07 & 0,05 & 0,04 & 0,03 & 0,04 & 0,24 & 0,047 \\
\hline 0,17 & 0,26 & 0,21 & 0,24 & 0,39 & 1,27 & 0,254 \\
\hline 0,10 & 0,16 & 0,07 & 0,08 & 0,04 & 0,45 & 0,090 \\
\hline 0,17 & 0,16 & 0,07 & 0,24 & 0,13 & 0,77 & 0,153 \\
\hline
\end{tabular}

Setelah melakukan penjumlahan maka dihasilkan hasil normalisasi matriks seperti Tabel 17 diatas.

\section{Mengukur Konsistensi Kriteria Harga Barang}

Nilai eigen maksimum ( $\lambda$ maksimum) dapat dicari dengan cara menjumlahkan hasil perkalian jumlah kolom dengan vektor eigen. Maka nilai eigen maksimum yang dapat diperoleh yaitu:

$$
\begin{aligned}
& \propto \max =5,33 \\
& \text { CI } \quad=\underline{\propto \max -\mathrm{n}} \\
& \mathrm{n}-1 \\
& =(5.33-5) /(5-1) \\
& =0.08
\end{aligned}
$$


Untuk $\mathrm{n}=5, \mathrm{RI}=1,120$ (Tabel Saaty), maka:

$\mathrm{CR}=\mathrm{CI} / \mathrm{RI}$

$$
=0.08 / 1.120
$$$$
=0.07
$$

Nilai 0,07 ini menyatakan bahwa rasio konsistensi dari hasil penilaian pembandingan di atas mempunyai rasio $7 \%$. Sehingga penilaian di atas dapat diterima karena lebih kecil dari 10\%.(Saaty, 2008)

\subsection{Penilaian Alternatif Terhadap Kriteria Pelayanan Pelangggan}

Berikut tabel pembobotan penilaian dan perbandingan berpasangan alternative terhadap kriteria:

Tabel 18. Matriks Alternatif Terhadap Kriteria Pelayanan Pelanggan

\begin{tabular}{cccccc}
\hline $\begin{array}{c}\text { C7 (Pelayanan } \\
\text { Pelanggan) }\end{array}$ & $\begin{array}{c}\text { CV } \\
\text { Garuda Jaya }\end{array}$ & $\begin{array}{c}\text { CV } \\
\text { Sulaiman Putra }\end{array}$ & $\begin{array}{c}\text { CV } \\
\text { Karya } \\
\text { Sekawan }\end{array}$ & $\begin{array}{c}\text { PT Karya Putra } \\
\text { Sangkuriang }\end{array}$ & $\begin{array}{c}\text { CV } \\
\text { Hutan Karet }\end{array}$ \\
\hline $\begin{array}{c}\text { CV Garuda } \\
\text { Jaya }\end{array}$ & 1,00 & 3,00 & 3,00 & 0,50 & 3,00 \\
\hline $\begin{array}{c}\text { CV Sulaiman } \\
\text { Putra }\end{array}$ & 0,33 & 1,00 & 0,33 & 0,20 & 0,50 \\
\hline $\begin{array}{c}\text { CV Karya } \\
\text { Sekawan }\end{array}$ & 0,33 & 3,00 & 1,00 & 0,14 & 3,00 \\
\hline $\begin{array}{c}\text { PT Karya Putra } \\
\text { Sangkuriang }\end{array}$ & 2,00 & 5,00 & 7,00 & 1,00 & 1,00 \\
\hline $\begin{array}{c}\text { CV Hutan } \\
\text { Karet }\end{array}$ & 0,33 & 2,00 & 2,00 & 0,33 & 8,00 \\
\hline$\sum$ & 4,00 & 14,00 & 13,33 & 2,18 & \\
\hline
\end{tabular}

Berikut adalah tabel 19. Matriks Alternatif Terhadap Kriteria Pelayanan Pelanggan, jika sudah memasukan bobot nilai maka lakukan tahapan seperti di bawah ini:

Tabel 19. Normalisasi Matriks Alternatif Terhadap Kriteria Pelayanan Pelanggan

\begin{tabular}{ccccccc}
\hline $\begin{array}{c}\text { CV } \\
\text { Garuda Jaya }\end{array}$ & $\begin{array}{c}\text { CV } \\
\text { Sulaiman } \\
\text { Putra }\end{array}$ & $\begin{array}{c}\text { CV } \\
\text { Karya } \\
\text { Sekawan }\end{array}$ & $\begin{array}{c}\text { PT Karya } \\
\text { Putra } \\
\text { Sangkuriang }\end{array}$ & $\begin{array}{c}\text { CV } \\
\text { Hutan Karet }\end{array}$ & $\sum$ & $\begin{array}{c}\text { Eigen } \\
\text { Faktor }\end{array}$ \\
\hline 0,25 & 0,21 & 0,23 & 0,23 & 0,38 & 1,29 & 0,259 \\
\hline 0,08 & 0,07 & 0,03 & 0,09 & 0,06 & 0,33 & 0,067 \\
\hline 0,08 & 0,21 & 0,08 & 0,07 & 0,06 & 0,50 & 0,100 \\
\hline 0,50 & 0,36 & 0,53 & 0,46 & 0,38 & 2,22 & 0,443 \\
\hline 0,08 & 0,14 & 0,15 & 0,15 & 0,13 & 0,65 & 0,131 \\
\hline
\end{tabular}


Setelah melakukan penjumlahan maka dihasilkan hasil normalisasi matriks seperti Tabel 19 diatas.

\section{Mengukur Konsistensi Kriteria Pelayanan Pelangggan}

Nilai eigen maksimum ( $\lambda$ maksimum) dapat dicari dengan cara menjumlahkan hasil perkalian jumlah kolom dengan vektor eigen. Maka nilai eigen maksimum yang dapat diperoleh yaitu:

$$
\begin{aligned}
\propto \max & =5,32 \\
\mathrm{CI} & =\frac{\propto \max -\mathrm{n}}{\mathrm{n}-1} \\
& =(5.32-5) /(5-1) \\
& =0.08
\end{aligned}
$$

Untuk n = 5, RI = 1,120,(Saaty, 2008) maka:

$$
\begin{aligned}
\mathrm{CR} & =\mathrm{CI} / \mathrm{RI} \\
& =0.08 / 1.120 \\
& =0.07
\end{aligned}
$$

Nilai 0,07 ini menyatakan bahwa rasio konsistensi dari hasil penilaian pembandingan di atas mempunyai rasio $7 \%$. Sehingga penilaian di atas dapat diterima karena lebih kecil dari 10\%.(Saaty, 2008)

\subsection{Perhitungan Total Ranking}

Setelah melakukan analisis alternatif maka didapat tabel data, hasil perangkingan di dapatkan dari hasil bagi rata-rata (eigen vector) kriteria dengan hasil rata-rata (eigen vector) masing-masing alternatif. Berikut tabel 20 hasil perankingan setelah di urutkan seperti di bawah ini : 
Tabel 20. Hasil Perangkingan

\begin{tabular}{|l|l|l|l|l|l|l|l|l|}
\hline \multicolumn{1}{|c|}{ Kriteria } & \multicolumn{1}{c|}{ C1 } & \multicolumn{1}{c|}{ C2 } & \multicolumn{1}{c|}{ C3 } & \multicolumn{1}{c|}{ C4 } & C5 & C6 & C7 & Ranking \\
\cline { 1 - 7 } Rata-rata & 0,12 & 0,07 & 0,06 & 0,29 & 0,15 & 0,27 & 0,04 & 0,361 \\
\hline $\begin{array}{l}\text { CV Garuda } \\
\text { Jaya }\end{array}$ & 0,481 & 0,136 & 0,302 & 0,301 & 0,377 & 0,456 & 0,259 & $0,0,056$ \\
\hline $\begin{array}{l}\text { CV } \\
\text { Sulaiman } \\
\text { Putra }\end{array}$ & 0,053 & 0,046 & 0,062 & 0,054 & 0,078 & 0,047 & 0,067 & 0,056 \\
\hline $\begin{array}{l}\text { CV Karya } \\
\text { Sekawan }\end{array}$ & 0,151 & 0,240 & 0,358 & 0,154 & 0,361 & 0,254 & 0,100 & 0,226 \\
\hline $\begin{array}{l}\text { PT Karya } \\
\text { Putra } \\
\text { Sangkuriang }\end{array}$ & 0,230 & 0,488 & 0,103 & 0,40 & 0,131 & 0,090 & 0,443 & 0,258 \\
\hline $\begin{array}{l}\text { CV. Hutan } \\
\text { Karet }\end{array}$ & 0,086 & 0,090 & 0,175 & 0,041 & 0,052 & 0,153 & 0,131 & 0,093 \\
\hline
\end{tabular}

Tabel 21. Urutan Hasil Perangkingan

\begin{tabular}{|c|c|c|}
\hline Urutan Prioritas & Alternatif & Nilai Akhir \\
\hline 1 & CV. Gauda Jaya & 0,361 \\
\hline 2 & PT Karya Putra Sangkuriang & 0,258 \\
\hline 3 & CV Karya Sekawan & 0,226 \\
\hline 4 & CV Hutan Karet & 0,093 \\
\hline 5 & CV Sulaiman Putra & 0,056 \\
\hline
\end{tabular}

Berdasarkan pengolahan data dan analisa yang telah dilakukan oleh penulis, maka hasil analisis dari perhitungan Analytical Hierarchy Process menyatakan bahwa alternatif yang terpilih dan paling sesuai dengan kriteria adalah Supplier CV Garuda Jaya berdasarkan tabel 3.22 Urutan Hasil Perankingan. Dengan perhitungan AHP yang diperoleh memberikan jawabannya dihitung dan didapat nilai akhir bahwa CV Garuda Jaya unggul dengan 36\% .

Faktor utama yang paling di prioritaskan dalam pemilihan supplier adalah kualitas barang dengan nilai bobot 0.28 atau $28 \%$, harga barang dengan nilai bobot 0.27 atau $27 \%$, dan supplier yang paling diprioritaskan adalah supplier CV Garuda Jaya dengan nilai bobot $36 \%$. 


\subsection{Perancangan dan Implementasi}

\subsubsection{Use Case Diagram}

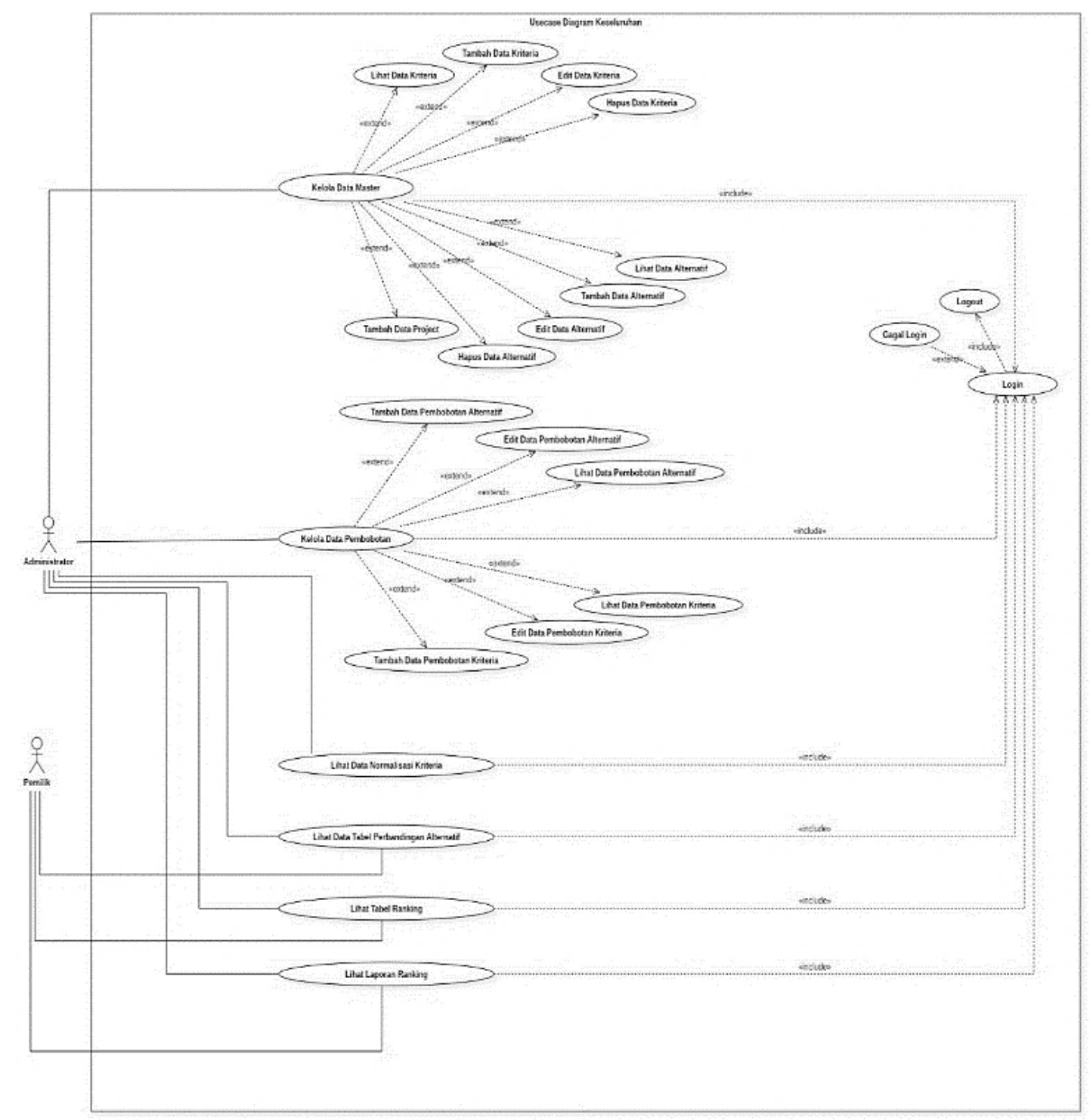

Gambar 1: Use Case Diagram Keseluruhan

Pada Gambar 5.1 merupakan use case keseluruhan dari perancangan aplikasi yang akan dibangun. Dalam perancangan system ini ada dua aktor yang berperan, administrator dan pemilik. Administrator bertugas untuk mengelola seluruh data dari mulai pengisian kriteria dan alternative sampai dengan perhitungan hingga hasil. Sementara pemilik hanya dapat melihat hasil dari perhitungan yang telah dikelola oleh administrator. 


\subsubsection{Implementasi}

Dalam form ini pengguna melakukan login dengan mengisi username dan password yang benar. Jika benar maka akan dialihkan ke halaman utama. Tampilan form login terdapat pada Gambar 2.

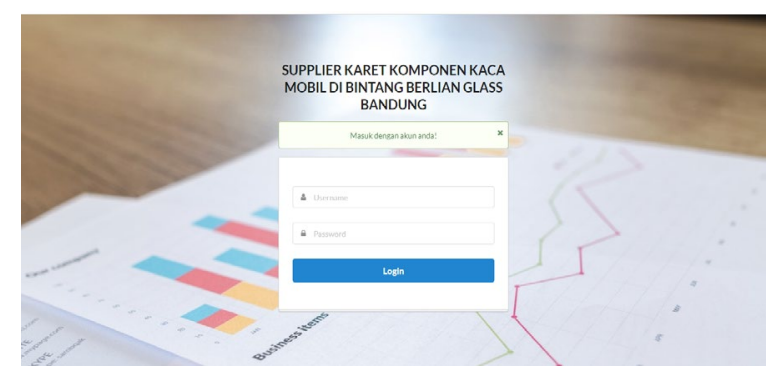

Gambar 2: Form Login

Dalam halaman utama terdapat tampilan dari Analitycal Hirearki Process (AHP). Halaman ini akan tampil setelah pengguna berhasil login. Tampilan halaman utama terdapat pada Gambar 3.

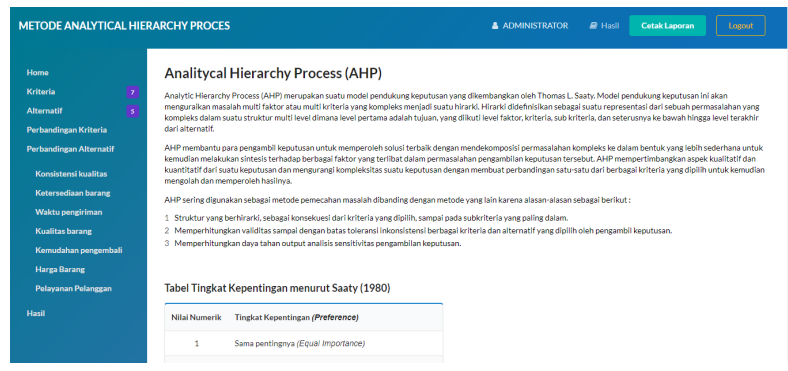

Gambar 3: Halaman Utama

Form kriteria untuk menginputkan kriteria-kriteria yang telah ditetapkan oleh perusahaan. Tampilan form input kriteria terdapat pada Gambar 4.

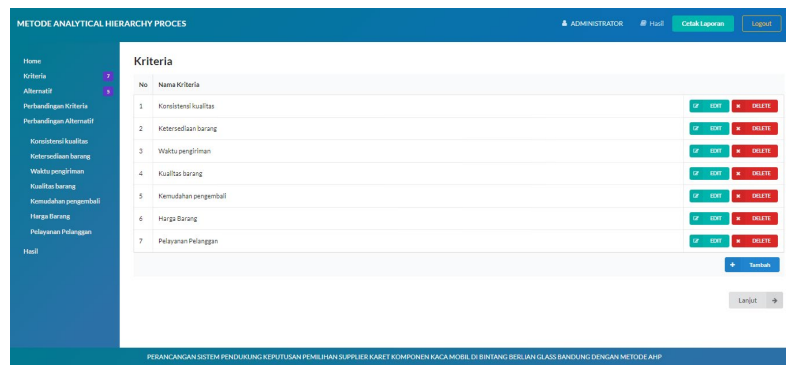

Gambar 4: Form Input Project 
Form ini digunakan untuk menginputkan data altenatif yaitu perusahaan mana saja yang akan dijadikan pilihan untuk menentukan supplier karet terbaik. Tampilan form input alternatif terdapat pada Gambar 5.

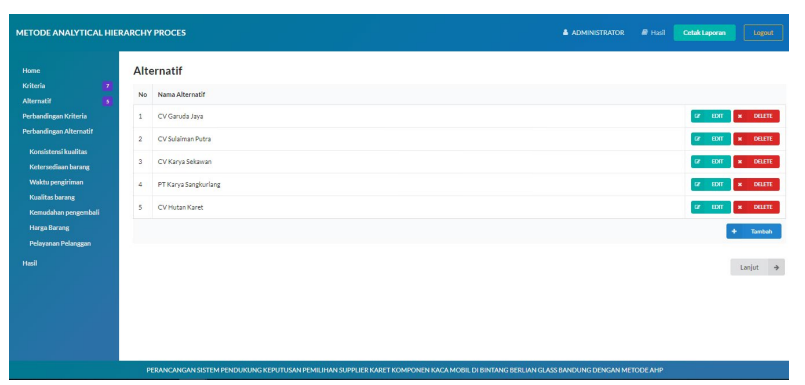

Gambar 5: Form Input Alternatif

Pada form ini digunakan untuk menginputkan bobot nilai dari data kriteria yang sudah diinputkan. Tampilan form input bobot nilai perbandingan kriteria terdapat pada Gambar 6.

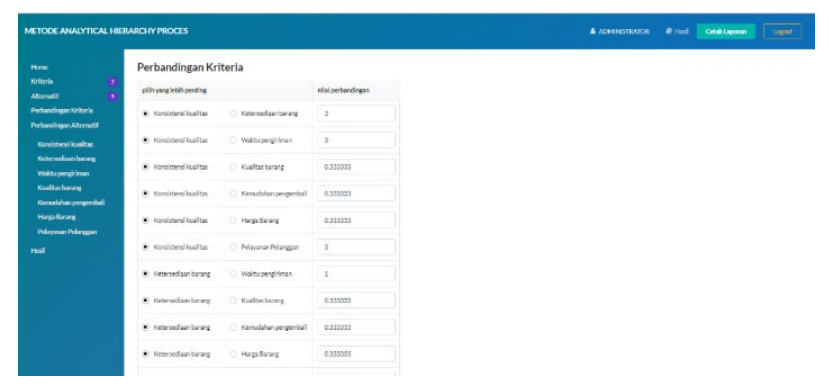

Gambar 6: Form Input Bobot Nilai Perbandingan Kriteria

Form nilai eigen krieria ini menampilkan data dari hasil proses perhitungan nilai rata-rata dari setiap kriteria untuk menentukan rangking. Tampilan form data nilai eigen kriteria terdapat pada Gambar 7.

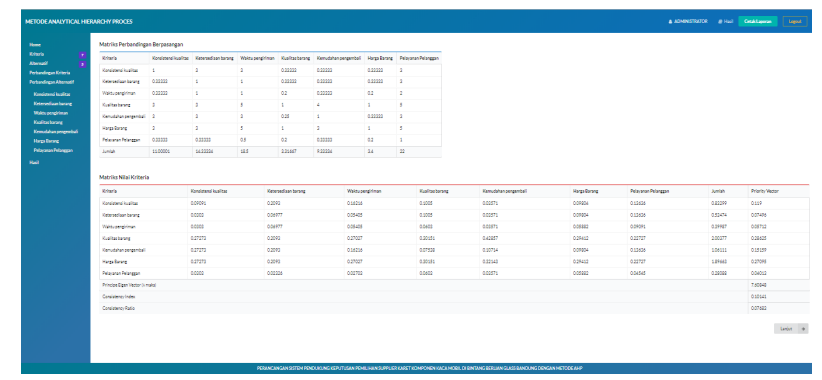

Gambar 7: Form Data Nilai Eigen Kriteria 
Form ini digunakan untuk menginputkan bobot nilai dari data alternatif yang sudah diinputkan. Tampilan form input bobot nilai alternatif terdapat pada Gambar 8 .

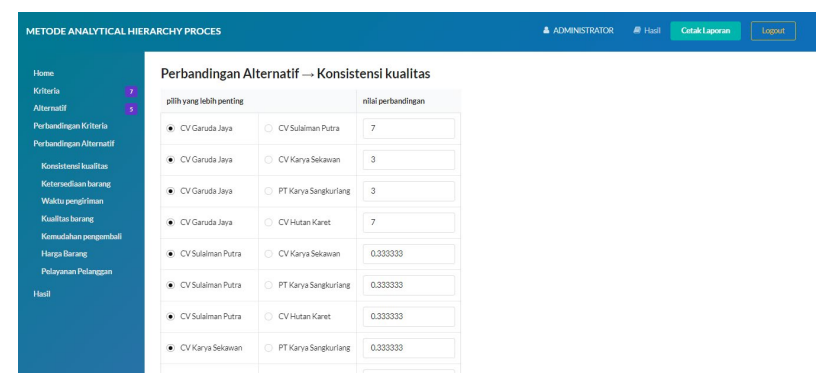

Gambar 8: Form Input Bobot Nilai Perbandingan Alternatif

Form nilai eigen alternatif ini menampilkan data dari hasil proses perhitungan nilai rata-rata dari setiap alternatif untuk menentukan rangking. Tampilan form data nilai eigen alternatif terdapat pada Gambar 9.

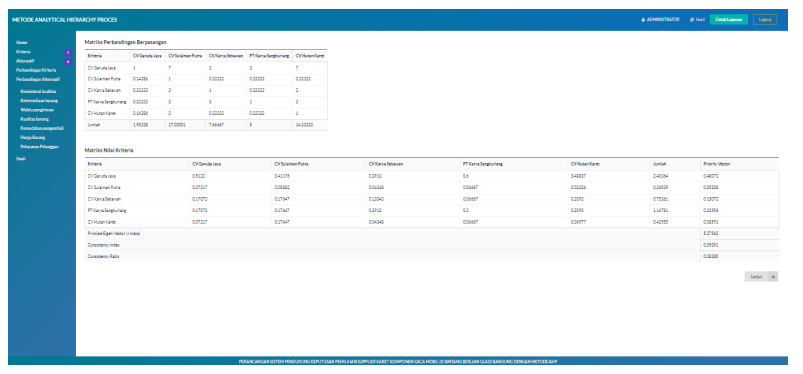

Gambar 9: Form Data Nilai Eigen Alternatif

Form rangking menampilkan data rangking dari setiap alternatif dengan bobot nilai terbesar. Tampilan form rangking terdapat pada Gambar 10.

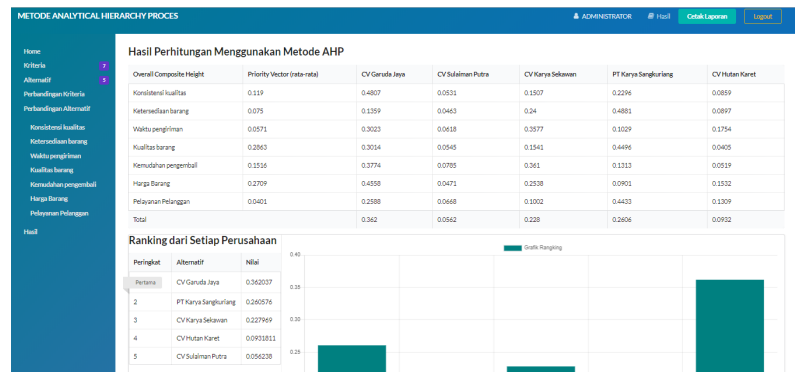

Gambar 10: Form Rangking 


\section{SIMPULAN}

Dari hasil penelitian dan pengamatan yang telah dilakukan pada Perusahaan Bintang Berlian Glass Bandung terhadap sistem pendukung keputusan pemilihan supplier yang diterapkan ini, maka penulis dapat menarik kesimpulan sebagai berikut:

1. Sistem pendukung keputusan (SPK) pemilihan supplier pada Perusahaan Bintang Berlian Glass Bandung bisa dijadikan dasar pengambilan keputusan manajemen dalam proses pemilihan supplier.

2. Keputusan yang dapat dipertanggung jawabkan dengan dukungan dari perhitungan yang dilakukan dengan AHP sebagai model dalam sistem pendukung keputusan.

3. Dengan diterapkannya sistem pendukung keputusan pemilihan supplier pada Perusahaan Bintang Berlian Glass Bandung akan memudahkan pihak manajemen dalam menentukan supplier.

\section{DAFTAR PUSTAKA}

Kurniawan Wahyu Haryanto. (2018). Sistem Pendukung Keputusan Pemilihan Supplier Bahan Baku Pada CV. Sinar Agung Perkasa Menggunakan Metode Analitycal Hierarchy Process (AHP). Jurnal SPIRIT: STMIK YADIKA Journal of Computing and Cybernetic System, 10.

Nurmalasari, \& Pratama, A. A. (2018). Sistem Pendukung Keputusan Pemilihan Supplier Menggunakan Metode AHP Pada PT Transcoal Pacific Jakarta. Jurnal Teknik Komputer AMIK BSI (JTK), IV(2), 48-55. https://doi.org/10.31294/jtk.v4i2.3509

Rosa Ariani Sukamto - Google Cendekia. (n.d.). Retrieved September 19, 2020, from https://scholar.google.co.id/citations?user=61vphZ0AAAAJ\&hl=id

Saaty, T. L. (2008). Decision making with the analytic hierarchy process - International Journal of Services Sciences - Volume 1, Number 1/2008 - Inderscience Publishers. International Journal of Services Sciences, 1(1), 83-98. https://doi.org/10.1504/IJSSci.2008.01759

Vaidya, O. S., \& Kumar, S. (2006). Analytic hierarchy process: An overview of applications. European Journal of Operational Research, 169(1), 1-29. https://doi.org/10.1016/j.ejor.2004.04.028 